\title{
Research Article GENDER DIFFERENTIALS IN ROLE PERFORMANCE IN FARMING AND ALLIED ACTIVITIES IN DANTIWADA TALUKA
}

\author{
JOSHI LEENA, AHLAWAT SANTOSH, SINGH SURABHI* AND CHAUDHARY M. K. \\ Sardarkrushinagar Dantiwada Agricultural University, Sardarkrushinagar, Dantiwada Taluka, Banaskantha District, Gujarat 385506 \\ *Corresponding Author: Email-surabhikshaunik@gmail.com
}

Received: November 02, 2017; Revised: January 08, 2018; Accepted: January 09, 2018; Published: January 15, 2018

\begin{abstract}
Women in India are the major work force in the agricultural sector. Involvement of women in agriculture varied greatly due to gender differences in various regions, cultures, economic status and even in crop selection. Genders roles are socially constructed specific roles decided based on cultural expectations of society. Gender roles vary in different sectors of development and are heavily influenced by cultural, social, and economic characteristics of the community. Hence, different roles are ascribed to men and women according to the socio-cultural and behavioral norms of the society. This research study was planned for creating a database on the gender role differentials prevailing in Banaskantha District in agriculture and allied fields. It will help to analyze and understand the factors responsible for gender differentials and to meet information need of stakeholders and policy planners.
\end{abstract}

Keywords- Gender differential, Role performance, Farming, Rural Women, Performance Level.

Citation: Joshi Leena, et al., (2018) Gender Differentials in Role Performance in Farming and Allied Activities in Dantiwada Taluka. International Journal of Agriculture Sciences, ISSN: 0975-3710 \& E-ISSN: 0975-9107, Volume 10, Issue 1, pp.-4976-4982. DOl: http://dx.doi.org/10.9735/0975-3710.10.1.4976-4982

Copyright: Copyright@2018 Joshi Leena, et al., This is an open-access article distributed under the terms of the Creative Commons Attribution License, which permits unrestricted use, distribution and reproduction in any medium, provided the original author and source are credited.

Academic Editor / Reviewer: Dr Om Prakash, Dr Satyanarayana C, Kumar Anil, P. K. Dhara

\section{Introduction}

Women in India make the major work force in the agricultural sector. If, we take the whole of India, more than 71.00 percent of women work as agricultural labourers which become 82.00 percent when it is confined to rural India. Women are doing most of the agricultural works but the benefit is going to the corporate and women still remain neglected². Further, women contribute 63.00 percent to agricultural production. They are the keepers of the commons and the indigenous seed heritage of the country. Yet, they are almost completely in the unorganised sector (71.00 percent) having no assets or economic security. Even though, Indian economy is growing at a rate of 9.00 , still 52.00 percent women of the country are suffering from malnutrition; they go hungry even when the granaries are full and overflowing [2]. The Food and Agriculture Organization (FAO) recognizes gender inequality as both a cause of and an effect of hunger and malnutrition [1]. There are lots of variations in involvement of women in agriculture due to gender differences in various regions, cultures, economic status and even in crop selection. Most of the women cultivators are involved in food crops rather than cash crops, since cash crops need more marketing efforts which are traditionally taken care by men. Women in higher socio-economic sections are usually not involved directly in cultivation or live stock, but they help in labor administration, supporting activities and accounting. It is also noticed that women are always involved in labour work and tolerance intensive works like transplantations and weeding operations etc. Further, women in agriculture are discriminated in payment of wages and they are underpaid to the extent of Rs. 93,000 Crores per year. Thus, Rs. 93,000 Crores is the extent to which women have been subsidising food production in India every year. The proportion of women agricultural labour is more than male labour in all the districts. With respect to gender gap, the participation gap has been narrowed but remuneration and advancement gap between male and female workers still exists [3]. Indian society even today has some gender boundaries, due to which women are often not defined as the farmers just like men. This is the reason that most of the women are marginal or small farmers, landless tenant farmers and mostly farm laborer. They don't have enough land to cultivate, have less knowledge, limited access to agricultural inputs especially to the innovative technologies, low capital and less credit facilities.

During last few decades, the government has made enough efforts to introduce the concept of gender equality and gender mainstreaming in all the sectors of development viz. politics, education and farming sector. Genders roles are socially constructed specific roles decided based on cultural expectations of society. Gender roles vary in different sectors of development and are heavily influenced by cultural, social, and economic characteristics of the community. Hence, different roles are ascribed to men and women according to the socio-cultural and behavioral norms of the society.

For creating a database on the gender role differentials prevailing in Banaskantha District in agriculture and allied fields, to analyze and understand the factors responsible for gender differentials and to meet information need of stakeholders and policy planners a research study was carried out with following specific objectives:

\section{Objectives of Study}

1. To study the personal and socio-economic profile of selected farm families

2. To find out gender differential in performance of various farming and allied activities

3. To study the gender differential in extent of time spent in farming and allied activities

4. To find out the gender differential in access and control over farming resources/inputs

5. To discover the reasons perceived for gender differentials in farming and allied activities

6. To find correlation between personal, socio-economic and communication profile of farm women and gender differential in farming and allied activities. 


\section{Research Methodology}

\section{Location of research study}

Present study was conducted in purposively selected Dantiwada taluka of Banaskantha District. Out of total 56 villages of Dantiwada taluka, twelve villages were selected randomly by Chit method. The main purpose of selecting Dantiwada taluka was non-availability of empirical data on gender differentials i.e., type of role performed by farm women in farming and allied activities, access and control over inputs required for farming, time spent by farm women in farming and allied activities.

\section{Sampling procedure and size}

One hundred sixty farm women were selected by stratified and proportionate random sampling procedure.

\section{Independent and dependent variables}

Personal, socio-economic and communication characteristics were studied as independent variables. Whereas, overall role performance level in farming and allied activities, types of roles performed, access and control over farming resources /inputs and time spend in farming and allied activities were studied as dependent variables.

\section{Data collection tool}

Pre-structured interview schedule was developed by investigator validity of which was checked by jury of experts. Reliability of total interview schedule was checked on twenty non-sampled respondents of non sampled villages of Dantiwada taluka. Data were collected by personal interview technique.

Responses of farm women on role performance level of farming and allied activities were recorded on three point scale i.e., performed by women alone, men alone and jointly by women and men Responses on type of role performed in farming and allied activities were taken on two point scale i.e., yes and No which were scored as 2 and 1respectly.Responses on access and control over resources were taken on three point scale i.e., full access, partial access and no access and full control, partial control and no control which were scored as three, two and one respectively.

\section{Analysis of Data}

Frequency, percentage, mean scores, ranks and't' test were used to analyze data on independent and dependent variables. Correlation co-efficient (' $r$ ') values were computed to find out the correlation between depended and independent variables.

\section{Results and Discussions}

\section{Personal and social variables of farm women}

Table-1 Distribution of respondents according to the personal and social profile $n=160$

\begin{tabular}{|l|c|c|}
\hline \multicolumn{1}{|c|}{ Personal and Social Variables } & Frequency & Percent \\
\hline Young (18-35 year) & 22 & 13.75 \\
\hline Middle (36-55 year) & 96 & 60.00 \\
\hline Old (Above 55 year) & 42 & 26.25 \\
\hline Education \\
\hline Illiterate \\
\hline Primary level & 96 & 60.00 \\
\hline Secondary level & 50 & 31.25 \\
\hline Type of Family & 14 & 8.75 \\
\hline Nuclear & 126 & 78.75 \\
\hline Joint & 34 & 21.25 \\
\hline Size of family & \multicolumn{1}{|l|}{} \\
\hline Small (4 members) & 44 & 27.50 \\
\hline Medium(5-8members) & 86 & 53.75 \\
\hline Large (>8 members) & 30 & 18.75 \\
\hline Caste & & \\
\hline General & 52 & 32.50 \\
\hline Other Backward Caste & 76 & 47.50 \\
\hline Scheduled Tribe & 24 & 15.00 \\
\hline Scheduled Caste & 8 & 5.00 \\
\hline
\end{tabular}

It is evident from data given in above [Table-1] that majority (60.00 percent) of farm women were of middle age group and illiterate. Only few $(8.75 \%)$ were educated up to secondary level. Majority $(78.75 \%)$ of farm women had nuclear type family. A little more than half ( 53.75 percent) of the farm women belonged to medium size families and 47.50 percent farm women belonged to other backward caste category. It can be concluded that the majority of farm women included in present study were of middle age group, illiterate, had nuclear type and medium size family and belonged to $\mathrm{OBC}$ caste category.

\section{Economic variables of farm women}

Data given in [Table-2] indicates that high majority ( 82.50 percent) of farm women belonged to low income group, belonged to medium size farmers' category $(57.5 \%)$, possessed medium size of herds $(60.00 \%)$, Semi pucca houses $(61.25 \%)$ and high majority $(82.50 \%)$ of them possessed one house only. Only 5.0 farm women belonged to the families which had annual income more than three lakhs. Only 2.50 percent farm women belonged to big farmer's families, only 21.25 percent families had large size herds, only 12.50 percent families had totally pucca house and only few $(5.0 \%)$ had more than two houses.

Table-2 Distribution of the respondents according to the economic variables. $n=160$

\begin{tabular}{|c|c|c|c|}
\hline Sr.No & Economic Variables & Frequency & Percent \\
\hline \multirow[t]{4}{*}{1} & \multicolumn{3}{|c|}{ Annual family income ( Rs.) } \\
\hline & $\operatorname{Low}(<1,50,000)$ & 132 & 82.50 \\
\hline & Medium $(1,50,000$ to $3,00,000)$ & 20 & 12.50 \\
\hline & High $(>3,00,000)$ & 8 & 5.00 \\
\hline \multirow[t]{5}{*}{2} & \multicolumn{3}{|c|}{ Type of farmers ( Based on land size) } \\
\hline & Marginal farmer (Up to $1.00 \mathrm{ha})$ & 28 & 17.5 \\
\hline & Small farmer (1.00 to $1.99 \mathrm{ha})$ & 36 & 22.5 \\
\hline & Medium farmer (2.00 to $9.99 \mathrm{ha})$ & 92 & 57.5 \\
\hline & Big farmer (Above $10.00 \mathrm{ha})$ & 04 & 2.5 \\
\hline \multirow[t]{4}{*}{3} & Herd size & & \\
\hline & Small ( $<6$ animals) & 30 & 18.75 \\
\hline & Medium (6 to 11 animals) & 96 & 60.00 \\
\hline & Large (> 11 animals) & 34 & 21.25 \\
\hline \multirow[t]{4}{*}{4} & Type of house & & \\
\hline & Kuchha & 42 & 26.25 \\
\hline & Semi pucca & 98 & 61.25 \\
\hline & Pucca & 20 & 12.5 \\
\hline \multirow[t]{4}{*}{5} & Number of house & & \\
\hline & One & 132 & 82.5 \\
\hline & Two & 20 & 12.5 \\
\hline & Above two & 8 & 5.0 \\
\hline
\end{tabular}

Communication variables of farm women:

Table-3 Distribution of respondents with according to the communication profile $n=160$

\begin{tabular}{|c|l|c|c|}
\hline Sr.No & \multicolumn{1}{|c|}{ Communication Variables } & Frequency & Percent \\
\hline \multirow{4}{*}{1} & Mass media exposure level & \multicolumn{2}{|c|}{} \\
\cline { 2 - 4 } & Low exposure (<10) & 120 & 75.00 \\
\cline { 2 - 4 } & Medium exposure (10 to 14) & 28 & 17.50 \\
\cline { 2 - 4 } & High exposure (>14) & 12 & 7.50 \\
\hline \multirow{2}{*}{2} & Contact with extension personnel's/agents & \multicolumn{2}{|c|}{} \\
\cline { 2 - 4 } & Low level contact (<9) & 122 & 76.25 \\
\cline { 2 - 4 } & Medium level contact (9 to 11) & 24 & 15.00 \\
\cline { 2 - 4 } & High level contact (> 11) & 14 & 8.75 \\
\hline 3 & Contact level with extension Institutes & 138 & 86.25 \\
\hline \multirow{2}{*}{} & Low contact (<9) & 18 & 11.25 \\
\hline & Medium contact (9 to 12) & 4 & 2.50 \\
\hline & High contact $>12)$ & \multicolumn{2}{|c}{} \\
\hline
\end{tabular}

Data given in [Table-3] Clearly indicated that majority $(75.00 \%)$ of farm women had low level of mass media exposure, low level of contacts with extension personnel's (76.25\%) and with extension institutes ( $86.25 \%$ ). It can be concluded that the communication profile of majority of farm women was low. Only few $(7.50 \%)$ had high level mass media exposure, high level contact with extension personnel's $(8.75 \%)$ and high level contact with extension institutes 
$(2.50 \%)$

\section{Gender differential in performance of various farming and allied activities}

Table-4 Gender differential in overall performance level of farming activities as perceived by farm women $(n=160)$

\begin{tabular}{|c|c|c|c|c|c|c|}
\hline \multicolumn{7}{|c|}{ Overall performance level of farming activities } \\
\hline $\begin{array}{l}\text { Sr. } \\
\text { No. }\end{array}$ & $\begin{array}{c}\text { Performan } \\
\text { ce level of } \\
\text { women }\end{array}$ & $\begin{array}{l}\text { Freq } \\
\text { uenc } \\
y\end{array}$ & $\begin{array}{l}\text { Percent } \\
\text { age }\end{array}$ & $\begin{array}{l}\text { Performance } \\
\text { level of men }\end{array}$ & $\begin{array}{l}\text { Freque } \\
\text { ncy }\end{array}$ & $\begin{array}{c}\text { Percen } \\
\text { tage }\end{array}$ \\
\hline 1. & Low $(<28)$ & 83 & 51.87 & Low $(<31)$ & 8 & 5.00 \\
\hline 2. & $\begin{array}{c}\text { Medium } \\
\text { (28 to 29) }\end{array}$ & 64 & 40.00 & $\begin{array}{l}\text { Medium } \\
\text { (31 to } 32 \text { ) }\end{array}$ & 48 & 30.00 \\
\hline 3. & High (>29) & 13 & 8.13 & High (> 32) & 104 & 65.00 \\
\hline & Total & 160 & 100.00 & Total & 160 & 100.00 \\
\hline
\end{tabular}

From the data given in [Table-4] clear-cut gender differential is depicted in overall performance level of women and men in farming activities. It is evident that overall performance level of 51.87 percent women was low in farming activities. Only 8.13 percent farm women perceived their role performance level as high. Whereas, overall role performance level of majority ( 65.00 percent) of men was perceived as high in farming activities by women. It can be concluded that farm women perceived high level of performance of men in farming activities in comparison of them. It might be due to the busy schedule of women in household and other dominated activities i.e., livestock activities which are mostly performed by women in the selected area of study.

Table-5 Gender differential in overall performance level of livestock activities as perceived by farm women. $(n=160)$

\begin{tabular}{|c|c|c|c|c|c|c|}
\hline \multicolumn{7}{|c|}{ Overall performance level in livestock activities } \\
\hline $\begin{array}{l}\text { Sr. } \\
\text { No. }\end{array}$ & $\begin{array}{c}\text { Performance } \\
\text { level of } \\
\text { women }\end{array}$ & Frequency & Percentage & $\begin{array}{l}\text { Performance } \\
\text { level of men }\end{array}$ & Frequency & Percentage \\
\hline 1. & Low $(<31)$ & 4 & 2.50 & Low $(<33)$ & 96 & 60.00 \\
\hline 2. & $\begin{array}{c}\text { Medium } \\
\text { (31 to } 32) \\
\end{array}$ & 42 & 26.25 & $\begin{array}{c}\text { Medium } \\
\text { (33 to 34) }\end{array}$ & 54 & 33.75 \\
\hline 3. & High (> 32) & 114 & 71.25 & High (> 34) & 10 & 6.25 \\
\hline & Total & 160 & 100.00 & Total & 160 & 100.00 \\
\hline
\end{tabular}

It is interesting to note the results regarding overall role performance level of farm women in livestock activities which are totally opposite to the role performance in farming. Clear-cut gender difference was perceived by farm women in livestock activities. It is evident from data that overall performance level of majority $(71.25$ percent) of farm women in livestock activities was perceived as high. Whereas, overall performance level of majority ( 60.00 percent) of men in livestock activities was perceived as low.

It can be concluding that overall performance level of women in livestock activities was perceived high and of men low.

Table-6 Gender differential in overall performance level of household activities as perceived by farm women $(n=160)$

\begin{tabular}{|c|c|c|c|c|c|c|}
\hline \multicolumn{7}{|c|}{ Overall performance level of household activities } \\
\hline $\begin{array}{l}\text { Sr. } \\
\text { No. }\end{array}$ & $\begin{array}{c}\text { Performance } \\
\text { level of } \\
\text { women }\end{array}$ & Frequency & Percentage & $\begin{array}{l}\text { Performance } \\
\text { level of men }\end{array}$ & Frequency & Percentage \\
\hline 1. & Low $(<25)$ & 2 & 1.25 & Low $(<27)$ & 139 & 86.87 \\
\hline 2. & $\begin{array}{l}\text { Medium } \\
(25 \text { to } 26)\end{array}$ & 16 & 10.00 & $\begin{array}{l}\text { Medium } \\
\text { (25 to } 26)\end{array}$ & 19 & 11.88 \\
\hline 3. & High (> 26) & 142 & 88.75 & High (> 26) & 2 & 1.25 \\
\hline & Total & 160 & 100.00 & Total & 160 & 100.00 \\
\hline
\end{tabular}

Similarly, high majority $(88.75 \%)$ of farm women had high level of overall role performance in household activities. Whereas, high majority ( $86.87 \%)$ of men had low level of role performance in household activities. Only negligible $(1.25 \%)$ number of women and men had low and high level of role performance in household activities respectively.

It can be concluded that performance level of farm women in household activities was perceived as high and of men as low.

\section{Gender Differential in Extent of Time Spent in Farming and Allied Activities}

It is evident from ranks given in [Table-7] that women in kharif season spent maximum time $(6.20 \mathrm{hrs} /$ day) in weeding followed by manual harvesting ( 6.18 $\mathrm{hrs} /$ day) and cleaning of farm produce. Whereas, men spent maximum time $(6.62$ $\mathrm{hrs} /$ day) in marketing of farm produce followed by manual harvesting ( 6.20 hrs/day) and seed treatment (5.99 hrs./day). Women spent minimum time in marketing of farm produce, storage of farm produce and seed treatment. Whereas, men' spent minimum time in cleaning of farm produce, drying of farm produce and irrigation activities. ' $t$ ' test was applied to find out statistical difference between the mean time spent by women and men in farming activities. ' $t$ ' value $\left(2.238^{* *}\right)$ reveled highly significant difference at 0.01 level of significance between the mean time spent by women and men. It can be inferred that women spent maximum mean time in more physical and drudgery prone farming activities and men spent maximum time in money and skill oriented farming activities.

\begin{tabular}{|c|c|c|c|c|c|c|}
\hline \multirow{3}{*}{$\begin{array}{l}\text { Sr. } \\
\text { No. }\end{array}$} & \multirow{3}{*}{ Farming activities } & \multicolumn{5}{|c|}{ Mean time spend in farming activities } \\
\hline & & \multicolumn{2}{|c|}{$\begin{array}{l}\text { Kharif } \\
\text { (hrs./day) }\end{array}$} & \multicolumn{2}{|c|}{$\begin{array}{c}\text { Kharif } \\
\text { (hrs./day) }\end{array}$} & \multirow{2}{*}{$\begin{array}{c}\text { 't' } \\
\text { value }\end{array}$} \\
\hline & & Women & Rank & Men & Rank & \\
\hline 1. & $\begin{array}{l}\text { Leveling and } \\
\text { making ridge }\end{array}$ & - & - & 5.96 & 4.5 & \multirow{18}{*}{$2.238^{* *}$} \\
\hline 2. & Clod breaking & 4.12 & 4 & 5.81 & 7 & \\
\hline 3. & Digging & 2.32 & 9 & 5.95 & 6 & \\
\hline 4. & Seed procurement & - & - & 4.43 & 9 & \\
\hline 5. & Seed treatment & 1.74 & 11 & 5.99 & 3 & \\
\hline 6. & Sowing & 2.83 & 8 & 5.96 & 4.5 & \\
\hline 7. & Irrigation & 2.9 & 10 & 2.83 & 16 & \\
\hline 8. & $\begin{array}{l}\text { Application of } \\
\text { fertilizer }\end{array}$ & - & - & 2.89 & 15 & \\
\hline 9. & $\begin{array}{l}\text { Application of } \\
\text { insecticide and } \\
\text { pesticides }\end{array}$ & - & - & 2.90 & 14 & \\
\hline 10. & Weeding & 6.20 & 1 & 4.23 & 10 & \\
\hline 11. & Manual harvesting & 6.18 & 2 & 6.2 & 2 & \\
\hline 12. & $\begin{array}{l}\text { Mechanical } \\
\text { harvesting }\end{array}$ & 3 & 7 & 3.89 & 11 & \\
\hline 13. & Threshing & 4.01 & 5 & 4.67 & 8 & \\
\hline 14. & $\begin{array}{l}\text { Cleaning of farm } \\
\text { produce }\end{array}$ & 6.17 & 3 & 2.38 & 18 & \\
\hline 15. & $\begin{array}{l}\text { Drying of farm } \\
\text { produce }\end{array}$ & 3.47 & 6 & 2.58 & 17 & \\
\hline 16. & $\begin{array}{l}\text { Storage of farm } \\
\text { produce }\end{array}$ & 1.03 & 12 & 3.05 & 12 & \\
\hline 17. & $\begin{array}{l}\text { Village level } \\
\text { marketing }\end{array}$ & 1.4 & 13 & 3.8 & 13 & \\
\hline 18. & $\begin{array}{l}\text { Marketing outside of } \\
\text { village }\end{array}$ & - & - & 6.62 & 1 & \\
\hline
\end{tabular}

Almost similar kind of time spend trend was observed in kharif and rabi seasons. It evident from the ranks given in [Table-8] that women spent maximum time $(6.31$ hrs./day) in weeding followed by manual harvesting ( $6.07 \mathrm{hrs} /$ /day) and cleaning of farm produce $(5.91 \mathrm{hrs} / \mathrm{day})$ during rabi seasons. Whereas, men' spent maximum time ( $6.40 \mathrm{hrs} /$ day) in marketing followed by manual harvesting (6.24 $\mathrm{hrs} /$ day) and digging (5.99 hrs./day). Women spent minimum time in marketing whereas men in drying of farm produce. It can be inferred that women spent in maximum time in crop management and post harvest activities. Whereas, men' spent maximum time in marketing and harvesting activities. Significant difference was observed at 0.01 levels of significance between the mean time spent by women and men in farming activities in rabi seasons. 


\begin{tabular}{|c|c|c|c|c|c|c|}
\hline \multirow{3}{*}{$\begin{array}{l}\text { Sr. } \\
\text { No. }\end{array}$} & \multirow{3}{*}{ Farming activities } & \multicolumn{5}{|c|}{ Mean time spent in farming activities } \\
\hline & & \multicolumn{2}{|c|}{$\begin{array}{c}\text { Rabi } \\
\text { (hrs./day) }\end{array}$} & \multicolumn{2}{|c|}{$\begin{array}{c}\text { Rabi } \\
\text { (hrs./day) }\end{array}$} & \multirow{2}{*}{$\begin{array}{c}\text { 't' } \\
\text { value }\end{array}$} \\
\hline & & Women & Rank & Men & Rank & \\
\hline 1. & Leveling and making ridge & 0 & - & 5.95 & 4.5 & \multirow{18}{*}{$2.10^{* *}$} \\
\hline 2. & Clod breaking & 4.12 & 6 & 5.83 & 6 & \\
\hline 3. & Digging & 2.05 & 10 & 5.99 & 3 & \\
\hline 4. & Seed procurement & 0 & - & 3.77 & 11 & \\
\hline 5. & Seed treatment & 1.57 & 11 & 2.95 & 17 & \\
\hline 6. & Sowing & 3.41 & 8 & 5.95 & 4.5 & \\
\hline 7. & Irrigation & 3.5 & 9 & 3.04 & 16 & \\
\hline 8. & Application of fertilizer & 0 & - & 3.13 & 12.5 & \\
\hline 9. & $\begin{array}{l}\text { Application of insecticide } \\
\text { and pesticides }\end{array}$ & 0 & - & 3.13 & 12.5 & \\
\hline 10. & Weeding & 6.31 & 1 & 4.32 & 8.5 & \\
\hline 11. & Manual harvesting & 6.07 & 2 & 6.24 & 1 & \\
\hline 12. & Machinery harvesting & 4.13 & 5 & 4.03 & 10 & \\
\hline 13. & Threshing & 4.29 & 4 & 4.32 & 8.5 & \\
\hline 14. & Cleaning of farm produce & 5.91 & 3 & 5.81 & 7 & \\
\hline 15. & Drying of farm produce & 3.57 & 7 & 2.37 & 18 & \\
\hline 16. & Storage of farm produce & 1.44 & 12 & 3.08 & 15 & \\
\hline 17. & Village level marketing & 1.2 & 13 & 3.8 & 14 & \\
\hline 18. & $\begin{array}{l}\text { Outside of village } \\
\text { marketing }\end{array}$ & 0 & - & 6.4 & 2 & \\
\hline
\end{tabular}

Table-9 Gender differentials in time spent in performance of livestock activities as perceived by farm women $(n=160)$

\begin{tabular}{|c|c|c|c|c|c|c|}
\hline \multirow[b]{2}{*}{$\begin{array}{l}\text { Sr. } \\
\text { No. }\end{array}$} & \multirow[b]{2}{*}{ Livestock activities } & \multicolumn{5}{|c|}{ Mean time spent in livestock activities } \\
\hline & & Women & Rank & Men & Rank & $\begin{array}{c}\text { 't' } \\
\text { value }\end{array}$ \\
\hline 1. & Fodder collection & 3.84 & 5 & 1.30 & 15 & \\
\hline 2. & $\begin{array}{l}\text { Chopping of straw and } \\
\text { fodder }\end{array}$ & 1.2 & 16 & 1 & 17 & \\
\hline 3. & Stall feeding & 1.89 & 12 & 1.70 & 12 & \\
\hline 4. & Taking animal for grazing & 2.46 & 7 & 1.33 & 14 & \\
\hline 5. & Watering the animals & 1.42 & 14 & 2 & 9 & \\
\hline 6. & Care of new born calf & 6.25 & 1 & 4.13 & 2 & \\
\hline 7. & Care of sick animal & 5.81 & 2 & 3.96 & 3 & \\
\hline 8. & Calling to veterinary doctor & 2.8 & 8 & 2.47 & 5 & \\
\hline 9. & Taking animal to hospital & 0 & - & 4.65 & 1 & \\
\hline 10. & Vaccination of livestock & 1.05 & 15 & 1.85 & 11 & \\
\hline 11. & Natural Service & 0 & - & 2.40 & 6.5 & \\
\hline 12. & Artificial insemination & 1 & 17.5 & 1.10 & 16 & \\
\hline 13. & Selection of breed & 0 & - & 1.35 & 13 & \\
\hline 14. & Cleaning of shed & 3.95 & 4 & 0 & & $0.322^{* *}$ \\
\hline 15. & Bathing of animal & 2.4 & 9.5 & 2 & 9 & \\
\hline 16. & Cleaning of utensils & 1.84 & 13 & 0 & - & \\
\hline 17. & $\begin{array}{l}\text { Dung collection and } \\
\text { making dung cakes }\end{array}$ & 4.31 & 3 & 0 & - & \\
\hline 18. & Hand milking & 2.3 & 11 & 2 & 9 & \\
\hline 19. & $\begin{array}{l}\text { Sending milk in village } \\
\text { dairy }\end{array}$ & 2.4 & 9.5 & 2.40 & 6.5 & \\
\hline 20. & Curd making & 0.56 & 19 & 0 & - & \\
\hline 21. & Ghee making & 2.63 & 6 & 0 & - & \\
\hline 22. & $\begin{array}{l}\text { Sale and purchase of } \\
\text { livestock }\end{array}$ & 1 & 17.5 & 3.68 & 4 & \\
\hline 23. & $\begin{array}{l}\text { Management of cash } \\
\text { received from marketing of } \\
\text { livestock and product }\end{array}$ & 0.43 & 20 & 0.57 & 18 & \\
\hline
\end{tabular}

Ranks given in [Table-9] showed that first three ranked livestock activities in which women spent maximum time were care of newly born calf $(6.25 \mathrm{hrs}$./day) followed by care of sick animal ( $5.81 \mathrm{hrs}$./day) and dung collection and making dung cakes (4.31 hrs./day). First three ranked activities in which men spent maximum time were taking sick animal to hospital( $4.65 \mathrm{hrs}$./day) followed by care of new born calf ( $4.13 \mathrm{hrs} . /$ day) and care of sick animals ( $3.96 \mathrm{hrs}$./day). It can be concluded that women spent maximum time in health management followed by shed management and feed management activities of livestock which are performed with in home premises. Whereas, men spent maximum time in the livestock activities which were actually performed outside home and require management of money.

Table-10 Gender differential in time spent in performance of household activities as perceived by farm women $(n=160)$

\begin{tabular}{|c|c|c|c|c|c|c|}
\hline \multirow{2}{*}{$\begin{array}{l}\text { Sr. } \\
\text { No. }\end{array}$} & \multirow[b]{2}{*}{ Household activities } & \multicolumn{5}{|c|}{ Mean time spends in household activities by } \\
\hline & & Women & Rank & Men & Rank & ' $\mathrm{t}$ ' \\
\hline 1. & $\begin{array}{l}\text { Cleaning and } \\
\text { maintenance of house }\end{array}$ & 0.45 & 7 & 0 & - & \multirow{20}{*}{$\begin{array}{l}0.157 \\
*\end{array}$} \\
\hline 2. & Washing cloths & 1.25 & 5 & 0 & - & \\
\hline 3. & Grinding of grains & 1.10 & 6 & 0.40 & 4 & \\
\hline 4. & $\begin{array}{l}\text { Repair and renovation of } \\
\text { house }\end{array}$ & 2 & 3 & 0 & - & \\
\hline 5. & Telephone bills & 0 & - & 0 & - & \\
\hline 6. & Electricity bills & 0 & - & 0 & - & \\
\hline 7. & Food preparation & 2.1 & 2 & 0 & - & \\
\hline 8. & Washing utensils & 0.40 & 9 & 0 & - & \\
\hline 9. & $\begin{array}{l}\text { Purchase of Fruit and } \\
\text { vegetables }\end{array}$ & 0.35 & 10 & 0.55 & 3 & \\
\hline 10. & Purchase of grocery item & 0 & - & 0 & - & \\
\hline 11. & Feeding to children & 0.42 & 8 & 0 & - & \\
\hline 12. & Bathing to children & 0.15 & 11 & 0 & - & \\
\hline 13. & Paying fee of children & 0 & - & 0 & - & \\
\hline 14. & $\begin{array}{l}\text { Attending parents } \\
\text { teacher meetings }\end{array}$ & 0 & - & 0 & - & \\
\hline 15. & $\begin{array}{l}\text { keep care of children's } \\
\text { homework }\end{array}$ & 1.50 & 4 & 2 & 2 & \\
\hline 16. & Care during sickness & 0 & - & 0 & - & \\
\hline 17. & $\begin{array}{l}\text { Looking after old } \\
\text { members }\end{array}$ & 7.25 & 1 & 2.05 & 1 & \\
\hline 18. & Purchase of clothing & 0 & - & 0 & - & \\
\hline 19. & Purchase of jewelry & 0 & - & 0 & - & \\
\hline 20. & $\begin{array}{l}\text { Planning and making } \\
\text { budget for household } \\
\text { expenditures }\end{array}$ & 0 & - & 0 & & \\
\hline
\end{tabular}

It is evident from the ranks given in [Table-10] that first three ranked household activities in which women spent maximum time were looking after old family members (7.25 hrs/day) followed by food preparation (2.1 hrs./day) and repair/renovation of house. Whereas, first three ranked activities in which men spent maximum time were almost similar to women i.e., looking after old family members ( $2.05 \mathrm{hrs}$./day) followed by keeping care of children's homework (2.00 hrs./day) and purchase of fruits and vegetables ( $0.55 \mathrm{hrs}$./day). It can be concluded that women spent maximum time in activities which are performed with in home premises and which are related to old age family members and children. Whereas, men spent maximum time in activities which usually are performed outside of home premises and are related to money and education.

\section{Gender Differential in Access to Resources/lnputs of Farming}

Table-11 Gender differential in access to farming resources/inputs as perceived by farm women $(n=160)$

\begin{tabular}{|c|c|c|c|c|c|c|}
\hline \multicolumn{7}{|c|}{ Overall level of accesses to resources/inputs } \\
\hline & \multicolumn{3}{|c|}{ Women } & \multicolumn{3}{|c|}{ Men } \\
\hline $\begin{array}{l}\text { Sr. } \\
\text { No. }\end{array}$ & $\begin{array}{l}\text { Level of } \\
\text { Access }\end{array}$ & Frequency & $\%$ & $\begin{array}{l}\text { Level of } \\
\text { Access }\end{array}$ & Frequency & $\%$ \\
\hline 1. & $\begin{array}{c}\operatorname{Low}(< \\
24)\end{array}$ & 125 & 78.12 & $\begin{array}{c}\text { Low }< \\
54) \\
\end{array}$ & 59 & 36.89 \\
\hline 2. & $\begin{array}{l}\text { Medium } \\
\text { (24 to 25) }\end{array}$ & 26 & 16.25 & $\begin{array}{c}\text { Medium } \\
\text { (54 to } \\
55 \text { ) }\end{array}$ & 92 & 57.50 \\
\hline 3. & $\begin{array}{c}\text { High }>> \\
25)\end{array}$ & 9 & 5.63 & $\begin{array}{c}\text { High (> } \\
55)\end{array}$ & 9 & 5.63 \\
\hline & Total & 160 & 100.00 & Total & 160 & 100.00 \\
\hline
\end{tabular}

It is evident from data given in [Table-11] that majority (78.12 percent) of farm women had low overall access to farming resources, whereas, the majority $(57.50 \%)$ of men had medium level of overall access to farming resources. However, only few $(5.63 \%)$ but equal cent women and men were perceived to have high access to farming resources. It can be concluded that overall access to 
farming resources to majority of women was low and to majority of men it was medium.

\section{Gender Differential in Control over Resources/Inputs of Farming}

Table-12 Gender differential in control over farming resources/inputs as perceive
by farm women( $n=160)$
\begin{tabular}{|c|c|c|c|c|c|c|}
\hline \multicolumn{7}{|c|}{ Overall level of control over resources/inputs } \\
\hline Women \\
\hline $\begin{array}{c}\text { Sr. } \\
\text { No. }\end{array}$ & $\begin{array}{c}\text { Level of } \\
\text { control }\end{array}$ & Frequency & $\%$ & $\begin{array}{c}\text { Level of } \\
\text { control }\end{array}$ & Frequency & $\%$ \\
\hline 1. & Low $(<24)$ & 131 & 81.87 & Low $(<49)$ & 71 & 44.53 \\
\hline 2. & $\begin{array}{c}\text { Medium } \\
(24 \text { to } 25)\end{array}$ & 20 & 12.50 & $\begin{array}{c}\text { Medium } \\
(49 \text { to } 50)\end{array}$ & 80 & 50.00 \\
\hline 3. & High $(>25)$ & 9 & 5.63 & High $(>50)$ & 9 & 5.63 \\
\hline \multicolumn{2}{|c|}{ Total } & 160 & 100.00 & Total & 160 & 100.00 \\
\hline
\end{tabular}

Data given [Table-12] reveled clear-cut gender difference in terms of control over resources because high majority ( $81.87 \%$ ) of farm women had low control over resources, whereas fifty percent of men had medium level of control over resources. Equal, but only few ( 5.63 percent) of women and men had high level of control over farming resources.

It can be concluded that high majority of women had low control over resources and majority of men had medium level of control over resources. Only few women and men had high level of control over farming resources.

\section{Reasons of gender differential perceived by farm women in farming and allied activities}

Table-13 Reasons perceived of gender differential by farm women in farming activities $(n=160)$

\begin{tabular}{|c|c|c|c|c|c|}
\hline Sr. No. & \multicolumn{2}{|c|}{ Farming activities } & Reasons perceived by women & f & $\%$ \\
\hline \multirow{3}{*}{1.} & \multirow{3}{*}{\multicolumn{2}{|c|}{ Leveling and making ridges }} & Women are not trained for drive the tractor. & 96 & 60.00 \\
\hline & & & Women not allowed to drive tractor because it is work of men & 64 & 40.00 \\
\hline & & & It is difficult to spare time for farm operation due to other domestic work & 104 & 65.00 \\
\hline \multirow{4}{*}{2.} & \multirow{2}{*}{ (a) } & \multirow{2}{*}{ Seed procurement } & Women have lack knowledge about improved seeds so they don't purchase the seeds. & 122 & 76.25 \\
\hline & & & Doing outside house work is the responsibility of men so men usually to purchase the seed & 160 & 100.00 \\
\hline & (b) & Seed treatment & $\begin{array}{l}\text { Women help men in seed treatment because women not actually know what amount of fertilizer } \\
\text { or chemical mixing in seed. }\end{array}$ & 160 & 100.00 \\
\hline & (c) & Sowing & Difficult to spent time for sowing due to domestic work by women & 160 & 100.00 \\
\hline \multirow{4}{*}{3.} & (a) & Irrigation & Irrigation is done by men because women's are busy in household and livestock activity. & 124 & 77.5 \\
\hline & \multirow{2}{*}{ (b) } & \multirow{2}{*}{$\begin{array}{l}\text { Application of fertilizer } \\
\text { and application of } \\
\text { insecticide and pesticides }\end{array}$} & $\begin{array}{l}\text { Application of fertilizer and application of insecticide and pesticides are done by men because } \\
\text { women do not have knowledge. }\end{array}$ & 122 & 76.25 \\
\hline & & & $\begin{array}{l}\text { Application of fertilizer and application of insecticide and pesticides are done by men because } \\
\text { women not know how much amount is needed for how much area. }\end{array}$ & 134 & 83.75 \\
\hline & (c) & Weeding & $\begin{array}{l}\text { Mostly weeding is done by women because men do not do properly due to lack of patience and } \\
\text { drudgery prone activity. }\end{array}$ & 160 & 100.00 \\
\hline \multirow{2}{*}{4.} & (a) & Manual harvesting & $\begin{array}{l}\text { Manual harvesting is done by women because women have practiced and can do with speed } \\
\text { compare to men. }\end{array}$ & 160 & 100.00 \\
\hline & (b) & Machine harvesting & $\begin{array}{l}\text { Mostly done by men because women lack technical knowledge about improved farming } \\
\text { equipments and to avoid any kind of miss happening. }\end{array}$ & 160 & 100.00 \\
\hline 5. & \multicolumn{2}{|c|}{ Cleaning and drying of farm produce } & $\begin{array}{l}\text { Cleaning and drying mostly done by women because since generations it is considered } \\
\text { responsibility of women. }\end{array}$ & 160 & 100.00 \\
\hline \multirow{2}{*}{6.} & \multirow{2}{*}{\multicolumn{2}{|c|}{ Village level and outside of village }} & $\begin{array}{l}\text { Marketing of farm produce is done by men because women not have knowledge about prevailing } \\
\text { market prices. }\end{array}$ & 160 & 100.00 \\
\hline & & & $\begin{array}{l}\text { Perceived traditional gender roles, Activities done outside the homestead are supposed to be } \\
\text { done by men and the homestead activities should be done by the women. }\end{array}$ & 160 & 100.00 \\
\hline
\end{tabular}

Farm women perceived that farming activities like leveling and making ridges, seed procurement, seed treatment, sowing, irrigation application of fertilizers, insecticides and pesticides and marketing of farm produce were the activities of men. The major reasons behind such perception of farm women were lack of knowledge, lack of skill, division of work by social system from generations and busy schedule of farm women in other domestic/household activities. Whereas, farm activities like weeding, manual harvesting, cleaning and drying of farm produce were perceived as activities of women. Farm women perceived that, women have practice of harvesting; therefore they can harvest crops more speedily than men. Farm women further perceived that since generations drying and cleaning of farm produce is being done by farm women as role ascribed by society and performed within the premises of home; therefore done by women.

Table-14 Reasons of gender differential perceived by farm women for in livestock activities ( $n=160)$

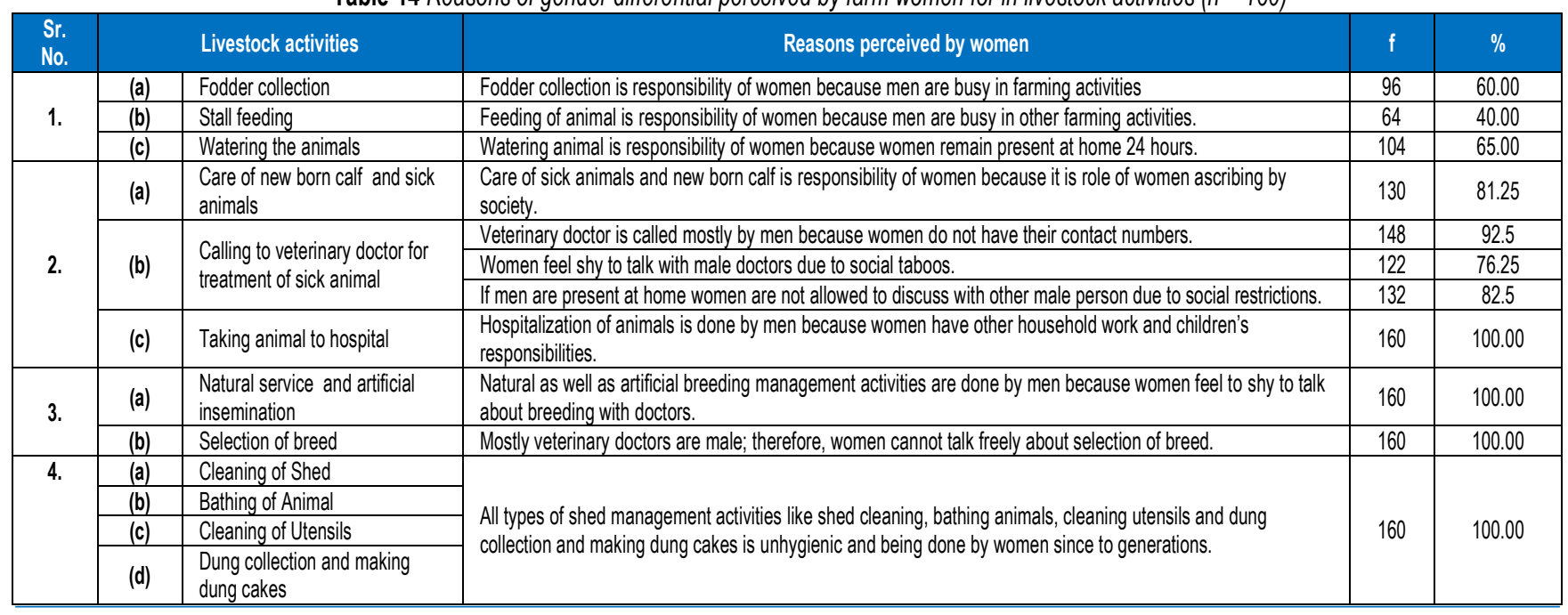


It is evident from the data given in [Table-14] that farm women perceived the livestock activities like taking animal to hospital, natural service and artificial insemination, selection of breed, sale and purchase of livestock, management of cash received from marketing of livestock and products as the activities of men. The major reasons were busy schedule of women in other household activities, women feel shy to talk about breeding and selection of breed with male doctors, they were not aware about prevailing prices as deal is done with males. Cash management is done by men being head of home and being it an outsides home activity, where women are not allowed due to social taboos.
Whereas, livestock activities like cleaning of shed, bathing of animal, cleaning of utensils, dung collection and making dung cakes were perceived as activities of women because, all types of shed management activities were perceived as unhygienic and being done by women since to generations.

It can be inferred from the findings that gender differential in livestock activities were mainly due to prevalence of wrong perceptions of social system, unhygienic nature of activities, social status men as head of home and time consumption as location of performance of livestock activities.

Table-15 Reasons of gender differential perceived by farm women in household activities ( $n=160)$

\begin{tabular}{|c|l|l|c|c|}
\hline $\begin{array}{c}\text { Sr. } \\
\text { No. }\end{array}$ & \multicolumn{1}{|c|}{ Household activities } & \multicolumn{1}{|c|}{ Reasons perceived by women } & $f$ & $\%$ \\
\hline 1. & Cleaning and maintenance of house & Cleaning and maintenance of house is the responsibility of women from generations & 160 & 100.00 \\
\hline 2. & Washing cloths & Washing of cloth is responsibility of women from beginning of society. & 160 & 100.00 \\
\hline 3. & Grind of grain & Grinding of grain is household work so it's a responsibility of women. & 127 & 79.37 \\
\hline 4. & Payment of electricity bill & $\begin{array}{l}\text { Paying electricity bill is responsibility of men because it is outside of household work and } \\
\text { related to money. }\end{array}$ & 160 & 100.00 \\
\hline 5. & Food preparation & Food preparation is the responsibility of women as ascribed by society. & 160 & 100.00 \\
\hline 6. & Washing utensils & Washing utensils is work of women as ascribed by society. & 160 & 100.00 \\
\hline 7. & $\begin{array}{l}\text { Purchase of fruits and vegetables and } \\
\text { grocery items. }\end{array}$ & $\begin{array}{l}\text { Purchase of fruits and vegetables is mostly done by men because, it's done outside of } \\
\text { home and is responsibility of men }\end{array}$ & 122 & 76.25 \\
\hline 8. & Feeding and bathing to children & Child and household work is responsibility of women as per society's customs. & 160 & 100.00 \\
\hline 9. & Paying fee of children & Due to iliteracy problem among women, men pay fees for children in schools. & 96 & 60.00 \\
\hline 10. & Care during sickness of children & $\begin{array}{l}\text { Care during sickness is always done by women because women have responsibility of } \\
\text { house and children. }\end{array}$ & 160 & 100.00 \\
\hline 11. & Looking after old members & Looking after old members is responsibility of women as per society's custom. & 160 & 100.00 \\
\hline 12. & Purchase of clothing and jewelry. & $\begin{array}{l}\text { Purchase of clothing and jewelry is jointly because payment of bill done by men. Women } \\
\text { do not have control over money but their choice is necessary. }\end{array}$ & 160 & 100.00 \\
\hline 13. & $\begin{array}{l}\text { Planning and making budget for } \\
\text { household expenditures }\end{array}$ & $\begin{array}{l}\text { Budget planning for household is done by women but money always given by men for } \\
\text { expenditure. }\end{array}$ & 160 & 100.00 \\
\hline
\end{tabular}

Various reasons of gender differential in household activities were perceived by farm women like payment of electricity bill and paying fee of children was perceived as the activities of men because there activities were being performed outside of home premises and were related to money.

Whereas, other household activities like cleaning and maintenance of house, washing clothes, grinding of grains, food preparation, washing utensils, feeding and bathing to children, care during sickness of children and old age persons were perceived as activities of women because of the reasons of traditional role of women or the role ascribed to women by the society.

It can be inferred from the findings that gender differential in household activities were mainly due to wrong perceptions of social system, no control of women over money, role ascribed by society since generations; time consumption and location of performance of household activities.

\begin{tabular}{|c|c|c|c|c|c|}
\hline \multirow[b]{2}{*}{$\begin{array}{l}\text { Sr. } \\
\text { No. }\end{array}$} & \multirow{2}{*}{\multicolumn{2}{|c|}{ Independent variables }} & \multicolumn{3}{|c|}{$\begin{array}{l}\text { Dependent variables } \\
\text { Co-efficient of correlation "r" value }\end{array}$} \\
\hline & & & $\begin{array}{l}\text { Performance level of women in } \\
\text { farming activities. } \\
\left(Y_{1}\right)\end{array}$ & $\begin{array}{l}\text { Performance level of women in } \\
\text { livestock activities } \\
\left(\mathrm{Y}_{2}\right)\end{array}$ & $\begin{array}{l}\text { Performance level of women } \\
\text { in house hold activities } \\
\left(Y_{3}\right)\end{array}$ \\
\hline 1. & Age & $\left(X_{1}\right)$ & $0.542^{* *}$ & $0.436^{* *}$ & $0.311^{*}$ \\
\hline 2. & Education & $\left(X_{2}\right)$ & $0.270^{* *}$ & $0.299^{* *}$ & $0.260^{*}$ \\
\hline 3. & Type of family & $\left(X_{3}\right)$ & $0.158^{*}$ & $0.180^{\circ}$ & $0.162^{*}$ \\
\hline 4. & Size of family & $\left(X_{4}\right)$ & $0.228^{* *}$ & $0.265^{* *}$ & $0.231^{*}$ \\
\hline 5. & Caste & $\left(X_{5}\right)$ & $0.075^{\mathrm{NS}}$ & $0.134 \mathrm{NS}$ & $-0.049 \mathrm{Ns}$ \\
\hline 6. & Annual income & $\left(X_{6}\right)$ & $0.322^{\prime \prime}$ & $0.324^{\prime \prime \prime}$ & $0.346^{* *}$ \\
\hline 7. & Size of land holding & $\left(X_{7}\right)$ & $0.234^{\prime \prime}$ & $0.221^{* *}$ & $0.260 "$ \\
\hline 8. & Herd size & $\left(\mathrm{X}_{8}\right)$ & $0.195^{*}$ & $0.171^{*}$ & $0.158^{*}$ \\
\hline 9. & Type of house & $\left(X_{9}\right)$ & $0.146^{\mathrm{NS}}$ & $-0.103^{\mathrm{NS}}$ & $0.151^{\mathrm{NS}}$ \\
\hline 10. & Number of house & $\left(X_{10}\right)$ & $0.234^{*}$ & $0.221^{* *}$ & $.269^{*}$ \\
\hline 11. & Mass media exposure & $\left(X_{11}\right)$ & $0.327^{\prime \prime}$ & $0.408^{* \prime}$ & $0.306^{\prime \prime}$ \\
\hline 12. & $\begin{array}{l}\text { Contact with extension } \\
\text { personnel's }\end{array}$ & $\left(X_{12}\right)$ & $0.318^{\prime \prime}$ & $0.331^{* *}$ & $0.374^{\prime \prime}$ \\
\hline 13. & $\begin{array}{l}\text { Contact with extension } \\
\text { institution }\end{array}$ & $\left(X_{13}\right)$ & $0.270^{* *}$ & $0.299^{* *}$ & $0.260 "$ \\
\hline
\end{tabular}

The data present in [Table-16] clearly indicate that variables like age, education; size of family, annual income, size of land holding, number of houses, mass media exposure, contact level with extension personnel's and extension institutions had positive and highly significant correlation at 0.001 level of significance with role performance level of women in farming, livestock and household activities.
Whereas, type of family and heard size had positive and significant correlation at 0.05 level of significance with role performance level of women in all three areas of farming, livestock and household activities. Only caste and type of house showed no significant correlation with performance level of women in farming, livestock and household activities. 


\section{Conclusion}

It can be concluded from major findings of study that majority of farm women were of middle age groups and illiterate; belonged to OBC category, had nuclear type and medium size families. Gender differentials were found in all aspects of role performance i.e., in farming as well as in allied activities. Majority of women were found performing low level of role in farming activities as compare to men. Majority of farm women were found performing high level of role in livestock activities as compared to men. High majority of farm women were found performing high level of role in household activities as compared to men. Role performance of majority of farm women was found in crop management and post-harvest activities. Whereas, role performance of majority to hundred percent of men was in land preparation, crop protection and marketing activities. Role performance of hundred percent of women in livestock were in shed management and feed management activities, whereas for men, it was in health management, breed management and marketing management. Farm women had low access as well as low control over farming resources; whereas, mean had medium level of access and control over farming resources. Major reasons of gender differential in farming and allied activities as perceived by farm women were socio-cultural perceptions of society, lack of technical knowledge and skill as well as high level of illiteracy among farm women; performance perfectness, time consumption; hygienic conditions; location as well as less or no control of women over farming resources.

Application of research: Majority of independent variables showed positive and highly significance correlation (except few) with overall performance role. Only two variables i.e., caste and type of house showed no significant correlation with performance level of women in farming, livestock and household activities.

Research Category: Agriculture Socio-economics

Acknowledgement / Funding: Author thankful to Sardarkrushinagar Dantiwada Agricultural University, Sardarkrushinagar, Dantiwada Taluka, Banaskantha, 385506, Gujarat, India.

*Research Guide or Chairperson of research: Dr M.K. Chaudhary University: Sardarkrushinagar Dantiwada Agricultural University, Sardarkrushinagar, Dantiwada Taluka, Banaskantha, 385506, Gujarat

Research project name or number: Nil

Authors 'contribution: Author 1 prepared tools for data collection and collected the data. Author 2 designed the research study and wrote the manuscript. Author 3 helped in designing research study and writing manuscript.

Author statement: All authors read, reviewed, agree and approved the final manuscript

\section{Conflict of Interest: None declared}

Ethical approval: This article does not contain any studies with human participants or animals performed by any of the authors.

\section{References}

[1] FAO. (2012) Gender and nutrition. http://www.fao.org/docrep/012/al184e/al184e00.pdf.

[2] Mahapatra S. (2012) Women contribute maximum to Indian economy but are still neglected. India, Rights of Women over land, livelihood and natural resources.

[3] Waris A., Nirmala B. and Kumar S. (2015) African Journal of Agricultural Research, 11(9), pp. 769-778. 